\title{
Masalah Plasenta Serta Kehamilan Multiple Terhadap Kejadian BBLR Di RSUD Kota Tasikmalaya
}

\section{Placental Problems and Multiple Pregnancy Against LBW Events In RSUD Kota Tasikmalaya}

\author{
Lia Herliana ${ }^{1^{*}}$, Mamat Purnama ${ }^{2}$ \\ 1,2 Jurusan Keperawatan Poltekkes Kemenkes Tasikmalaya, Indonesia. \\ Email: ${ }^{*}$ liaherliana3@gmail.com
}

\begin{abstract}
ABSTRAK
Bayi BBLR yang seringkali menjadikan beresiko tidak saja karena komplikasi neonatal yang dialami tetapi juga oleh faktor resiko lainnya (misal anomali bawaan yang dikaitkan dengan BBLR). Penelitian ini dilatarbelakangi oleh tingginya angka kejadian BBLR di RSUD Kota Tasikmalaya pada setiap tahunnya. Tujuan penelitian adalah untuk mengetahui adanya hubungan antara masalah plasenta dan kehamilan multiple dengan kejadian BBLR. Hipotesis penelitian ada hubungan antara masalah plasenta dan kehamilan multiple dengan kejadian BBLR. Manfaat penelitian memberikan dasar praktek berbasis bukti ilmiah (evidences based practice) kepada praktisi keperawatan, bahwa ada hubungan antara masalah plasenta dan kehamilan multiple dengan kejadian BBLR. Metode penelitian kuantitatif dengan pendekatan cross sectional. Pengolahan data menggunakan analisis univariat dan bivariat. Hasil penelitian tidak ada hubungan yang signifikan antara masalah plasenta serta kehamilan multiple dengan kejadian BBLR di RSUD Kota Tasikmalaya dengan $p$ value $>0,05$ untuk semua variable.. Saran hendaknya perawat lebih meningkatkan pendidikan kesehatan pada masyarakat agar masyarakat lebih memahami tentang resiko terjadinya BBLR.
\end{abstract}

Kata kunci: masalah plasenta, kehamilan multiple, BBLR

\begin{abstract}
LBW babies often make a risk not only because of neonatal complications experienced but also by other risk factors (eg congenital anomalies associated with LBW). Background of this research is the high incidence of LBW in Tasikmalaya City General Hospital every year. The purpose of the study was to determine the relationship between placental problems and multiple pregnancies with the incidence of $L B W$. The research hypothesis is that there is a relationship between placental problems and multiple pregnancies with the incidence of LBW. The benefits of the study provide a basis for evidence-based practice of nursing practitioners, that there is a relationship between placental problems and multiple pregnancies with the incidence of LBW. Method of research is Quantitative with cross sectional approach. Processing data using univariate and bivariate analysis. The results of the study showed no significant relationship between placental problems and multiple pregnancies with the incidence of LBW in Tasikmalaya City General Hospital with $p$ value $>0.05$ for all variables. Suggestions should nurses further improve health education in the community so that people better understand the risk of LBW.
\end{abstract}

Keywords: placental problems, multiple pregnancies, LBW

\section{PENDAHULUAN}

Bayi berat lahir rendah (BBLR) merupakan permasalahan serius yang dihadapi oleh dunia(1). Di Indonesia kejadian BBLR bervariasi secara nasional. Menurut SDKI 2002-2003 kejadian BBLR sebesar 6\%(2)(3). Kejadian BBLR berdasarkan provinsi bervariasi dengan rentang $2 \%-15,1 \%$. Di Jawa Barat BBLR merupakan penyebab kematian bayi (usia 0-1 tahun) nomor 3 pada tahun $1998(8,5 \%)$ dan nomor 4 pada tahun 1999 (8,71\%)(3). BBLR seringkali menjadikan bayi beresiko tidak saja karena komplikasi neonatal yang dialami (misal hiperbilirubinemia dan sindrom gawat nafas) tetapi juga oleh faktor resiko lainnya (misal anomali bawaan yang dikaitkan dengan BBLR). BBLR memerlukan penatalaksanaan yang tepat oleh seorang perawat karena apabila tidak mendapatkan perawatan yang adekuat(4), BBLR akan 
menimbulkan dampak terhadap sistem pernafasan, sistem penglihatan, refleks, gerakangerakan motorik bahkan dampak jangka panjang yaitu kesulitan belajar dan tingkah laku (neurobehaviour)(5). Beberapa penelitian telah dilakukan yang berkaitan dengan dampak BBLR terhadap anak dalam tahap pertumbuhan dan perkembangan berikutnya. Vohr et al (2000) melakukan penelitian prospektif terhadap bayibayi prematur tentang faktor-faktor yang mempengaruhi perkembangan neurologi dan hasil fungsional pada anak usia sekolah dimana didapatkan hasil bahwa anak dengan riwayat prematur yang disertai dengan intraventrikular haemoragik (IVH) memiliki frekuensi lebih banyak untuk terjadinya serebral palsy, gangguan pendengaran, skore rendah terhadap perawatan diri sehari-hari, IQ yang rendah, kosa kata, membaca dan penghitungan matematik(6). Faktor lain yang mempengaruhi adalah faktor biologik, lingkungan sosial, pengetahuan ibu serta bahasa percakapan sehari-hari yang digunakan di rumah juga memberikan kontribusi terhadap pencapaian hasil optimal pada anak usia sekolah. Penelitian lain yang juga meneliti tentang pencapaian tingkat kognitif bagi anak sekolah adalah Hack et al (2003) dimana menyatakan bahwa bayi berat lahir rendah dan prematuritas serta ukuran kepala yang abnormal berdampak pada kemampuan kognitif, neurofungsional dan pengaturan fisik anak pada saat usia sekolah(7). Lain halnya dengan Saigal (2002) yang menyatakan bahwa tidak ada hubungan yang signifikan antara remaja dengan riwayat prematur dan remaja yang dilahirkan cukup bulan dalam hal harga diri (self esteem(5).

Bayi yang dilahirkan prematur dan berat badan rendah sangat beresiko untuk terjadinya gangguan mental dan perkembangan motorik terutama pada bayi yang dirawat di NICU)(5). Pada umumnya, bayi prematur dan berat badan lahir sangat rendah juga memiliki insiden yang tinggi untuk terjadinya keterlambatan mental dan kondisi kecacatan. Diperkirakan setengah dari bayi berat lahir sangat rendah $(B B<1500$ gr) mengalami resiko kerusakan SSP (susunan syaraf pusat) akibat perdarahan intraventrikular yang juga menimbulkan resiko peningkatan kejadian kecacatan atau disabilitas (8). Insidens prematuritas dan BBLR paling rendah pada kelas ekonomi menengah ke atas, karena wanita hamil pada kelompok tersebut biasanya dalam kondisi kesehatan yang baik, cukup gizi dan mendapat asuhan prenatal awal dan komprehensif. Insidens tertinggi terjadi pada kelas sosial ekonomi rendah dengan kombinasi keadaan yang buruk. Faktor lain seperti kehamilan multiple, hipertensi akibat kehamilandan masalah plasenta yang menganggu perjalanan normal gestasi sebelum perkembangan fetal selesai, berperan terhadap sebagian besar kelahiran prematur dan BBLR (1). Sulit untuk menentukan secara pasti penyebab dari BBLR, tetapi ada beberapa faktor resiko yang erat kaitannya dengan kejadian BBLR, yaitu umur ibu saat melahirkan, usia kehamilan saat melahirkan, tingkat pendidikan ibu dan jenis kelamin bayi yang dilahirkan(2).

Dari hasil-hasil penelitian yang telah dilakukan dapat dilihat bahwa kelahiran prematur dan BBLR sangat berpengaruh terhadap perkembangan anak di kemudian hari (9), untuk itu diperlukan upaya-upaya yang sifatnya promotif untuk mencegah dan meminimalisir kejadian prematuritas dan BBLR agar anak sebagai investasi bangsa di masa depan dapat lebih berkualitas dengan melakukan analisis terhadap faktor-faktor apa saja yang mempengaruhi kejadian BBLR di RSUD Kota Tasikmalaya.

Hasil studi pendahuluan di RSUD Kota Tasikmalaya didapatkan angka kejadian BBLR pada tahun 2012 adalah 783 dari 4672 kelahiran atau sekitar $16,76 \%$. Dilihat dari angka tersebut jelas bahwa kejadian BBLR di RSUD Kota Tasikmalaya masih terhitung besar, maka perlu kiranya memperhatikan faktor-faktor apa saja yang mempengaruhi kejadian BBLR tersebut.

\section{METODE}

Jenis dan rancangan penelitian yang digunakan adalah kuantitatif dengan pendekatan cross sectional, dimana pengukuran variabelvariabelnya dilakukan hanya satu kali (10). Populasi penelitian adalah semua ibu yang memiliki bayi dan dirawat di RSUD Kota Tasikmalaya dengan sampel penelitian adalah ibu yang memiliki bayi yang dirawat di Ruang Perinatologi, NICU dan Ponek RSUD Kota Tasikmalaya pada periode bulan September s.d. Desember 2015. Teknik pengambilan sampel accidental sampling, dengan criteria inklusi: 1) lbu yang memiliki bayi yang dirawat di Ruang Perinatologi, NICU dan Ponek RSUD Dr. Soekardjo Kota Tasikmalaya baik yang lahir dengan BBLR atau tidak, 2) Usia kehamilan pada saat dilahirkan pada kisaran 36 - 42 minggu (aterm), 3) Kondisi bayi dan ibu sehat, 4) Ibu bisa tulis dan baca serta 5) Ibu melahirkan di RSUD Kota Tasikmalaya atau di luar RSUD Kota 
Tasikmalaya (11). Pengumpulan data dilakukan dengan kuesioner, dan analisis yang dilakukan meliputi univariat dan bivariat (chi-square).

\section{HASIL}

Penelitian ini dilaksanakan mulai tanggal 29 September sampai dengan 27 Oktober 2015 terhadap 65 responden. Di bawah ini disampaikan tabel hasil penelitian sebagai berikut (12):

a. Karakteristik kelahiran bayi

Tabel 1. Distribusi kelahiran bayi berdasarkan berat-badan

\begin{tabular}{lll}
\hline Kejadian bblr & Jumlah & Prosentase \\
\hline bblr & 22 & 33,8 \\
Tidak bblr & 43 & 66,2 \\
\hline Jumlah & $\mathbf{6 5}$ & $\mathbf{1 0 0}$
\end{tabular}

Dari tabel 5.di atas dapat dilihat bahwa ternyata sebagian responden tidak mengalami kejadian BBLR yaitu sebanyak $66,2 \%$, sedangkan $33,8 \%$ mengalami BBLR.

b. Distribusi kejadian masalah plasenta

Tabel 2. Distribusi responden berdasarkan masalah plasenta

\begin{tabular}{cll}
\hline $\begin{array}{c}\text { Masalah } \\
\text { plasenta }\end{array}$ & Jumlah & Prosentase \\
\hline Ya & 10 & 15,4 \\
Tidak & 55 & 84,6 \\
\hline Jumlah & $\mathbf{6 5}$ & $\mathbf{1 0 0}$ \\
\hline
\end{tabular}

Tabel 2 memperlihatkan bahwa sebanyak $84,6 \%$ responden tidak mengalami masalah pada plasenta saat kehamilan sedangkan $15,4 \%$ mengalaminya.

c. Distibusi responden berdasarkan kehamilan multiple
Tabel 3. Distribusi responden berdasarkan kehamilan multiple

\begin{tabular}{cll}
\hline $\begin{array}{c}\text { Kehamilan } \\
\text { multiple }\end{array}$ & Jumlah & Prosentase \\
\hline Ya & 11 & 16,9 \\
Tidak & 54 & 83,1 \\
\hline Jumlah & 65 & $\mathbf{1 0 0}$ \\
\hline
\end{tabular}

Pada tabel 3 diatas dapat dilihat sebanyak $83,1 \%$ responden kebanyakan tidak mengalami kehamilan multiple (kembar), sedangkan sisanya 16,9\% mengalami kehamilan multiple.

d. Tabel silang hubungan antara masalah plasenta dan kehamilan dengan kelahiran BBLR

Dalam penelitian ini analisis bivariat dilakukan untuk mengetahui gambaran hubungan antara variabel independent yaitu faktor-faktor yang berhubungan dengan kejadian BBLR dan variabel dependent yaitu kejadian BBLR.

Tabel 4. Tabel silang antara masalah plasenta dan kehamilan multiple dengan kejadian BBLR

\begin{tabular}{|c|c|c|c|c|c|c|c|}
\hline \multirow{3}{*}{ Variabel } & \multicolumn{4}{|c|}{ Kejadian BBLR } & \multirow{3}{*}{$\underset{\text { value }}{\mathrm{P}}$} & \multirow{3}{*}{ OR } & \multirow{3}{*}{$\begin{array}{c}95 \% \\
\text { Cl }\end{array}$} \\
\hline & \multicolumn{2}{|c|}{ BBLR } & \multicolumn{2}{|c|}{$\begin{array}{l}\text { Tidak } \\
\text { BBLR }\end{array}$} & & & \\
\hline & $\Sigma$ & $\%$ & $\Sigma$ & $\%$ & & & \\
\hline \multicolumn{8}{|l|}{$\begin{array}{l}\text { Kehamilan } \\
\text { multiple }\end{array}$} \\
\hline a.Ya & 5 & 22,7 & 6 & 14 & 0,587 & $\begin{array}{l}1,8 \\
14\end{array}$ & - \\
\hline b.Tidak & 17 & 77,3 & 37 & 86 & & & 6,679 \\
\hline Jumlah & 22 & 100 & 43 & 100 & & & \\
\hline \multicolumn{8}{|l|}{ Masalah } \\
\hline a. Ya & 3 & 13,6 & 7 & 16,3 & 1,000 & $\begin{array}{l}0,8 \\
12\end{array}$ & - \\
\hline b. Tidak & 19 & 84,4 & 36 & 83,7 & & & 3,504 \\
\hline Jumlah & 22 & 100 & 43 & 100 & & & \\
\hline
\end{tabular}

Pada tabel 4 di atas menunjukkan bahwa faktor kehamilan multiple (kembar) sebagian besar kejadian BBLR dialami oleh ibu-ibu dengan kehamilan yang tidak kembar yaitu sebanyak $77,3 \%$ demikian juga kejadian tidak BBLR banyak dialami oleh ibu-ibu dengan kehamilan tidak kembar yaitu sebanyak $86 \%$. Hasil pengujian statistik didapatkan $p$ value $=0,587$ artinya $\alpha>0,05$ 
dengan demikian dapat disimpulkan bahwa tidak ada hubungan antara kehamilan multiple dengan kejadian BBLR. Dari hasil analisis juga diperoleh OR 1,814 yang artinya ibu-ibu dengan kehamilan multiple memperoleh peluang sebesar 1,814 kali untuk terjadinya BBLR dibanding dengan ibu-ibu yang tidak mengalami kehamilan multiple. Untuk faktor masalah plasenta sebagian besar kejadian BBLR dialami oleh ibu-ibu dengan tidak memiliki riwayat masalah plasenta pada kehamilan yaitu sebanyak 84,4\% demikian juga kejadian tidak BBLR banyak dialami oleh ibu-ibu dengan riwayat tidak hipertensi yaitu sebanyak 83,7\%. Hasil pengujian statistik didapatkan $p$ value $=1,00$ artinya $\alpha>0,05$ dengan demikian dapat disimpulkan bahwa tidak ada hubungan antara masalah plasenta dengan kejadian BBLR. Dari hasil analisis juga diperoleh OR 0,812 yang artinya ibu-ibu dengan masalah plasenta pada kehamilan memperoleh peluang sebesar 0,812 kali untuk terjadinya BBLR dibanding dengan ibuibu yang tidak mengalami masalah plasenta.

\section{PEMBAHASAN}

a. Hubungan antara kehamilan multiple dengan kejadian BBLR(13)

Berat badan janin pada kehamilan kembar lebih ringan daripada janin pada kehamilan tunggal pada umur kehamilan yang sama. Sampai kehamilan 30 minggu kenaikan berat badan janin kembar sama dengan janin kehamilan tunggal. Setelah itu, kenaikan berat badan lebih kecil, mungkin karena regangan yang berlebihan menyebabkan peredaran darah plasenta mengurang. Berat badan satu janin pada kehamilan kembar rata-rata 1000 gram lebih ringan daripada janin kehamilan tunggal. Berat badan bayi yang baru lahir umumnya pada kehamilan kembar kurang dari 2500 gram.Suatu faktor penting dalam hal ini ialah kecenderungan terjadinya partus prematurus. Berat badan kedua janin pada kehamilan kembar tidak sama, dapat berbeda antara 50 sampai 1.000 gram, karena pembagian darah pada placenta untuk kedua janin tidak sama. Regangan pada uterus yang berlebihan kehamilan ganda salah satu faktor yang menyebabkan kelahiran BBLR. Pada kehamilan ganda distensi uterus berlebihan, sehingga melewati batas toleransi dan sering terjadi partus prematus. Kebutuhan ibu akan zat-zat makanan pada kehamilan ganda bertambah yang dapat menyebabkan anemia dan penyakit defisiensi lain, sehingga sering lahir bayi yang kecil. Kematian perinatal anak kembar lebih tinggi daripada anak dengan kehamilan tunggal dan prematuritas merupakan penyebab utama.

b. Hubungan antara masalah plasenta dengan kejadian BBLR (4)

Plasenta berperan penting dalam menjaga pertumbuhan janin dengan baik, karena semua zat yang diperlukan untuk pertumbuhan janin dihantarkan melalui plasenta. Beberapa fungsi plasenta lainnya adalah: 1) Pertukaran ekskresi; Janin belum memiliki kemampuan untuk mengeluarkan ekskresi atau zat sisa metabolisme nutrisi makanan yang didapatkan dari ibu, zat sisa metabolisme ini harus dikeluarkan dari tubuh janin karena bersifat racun. Plasenta pada bayi ini berguna untuk mengeluarkan zat sisa metabolisme janin menuju aliran darah ibu untuk diproses dan dikeluarkan oleh ginjal. 2) Jalur nutrisi(14); Plasenta juga diperlukan sebagai sarana transportasi pemberian segala macam nutrisi makanan yang berasal dari ibu hamil dan diperlukan oleh janin untuk tumbuh dan berkembang. Oleh karena plasenta ini terhubung dengan aliran darah ibu hamil, maka ibu hamil sebaiknya melakukan seleksi tentang asupan makanan atau minuman yang dikonsumsi agar tidak memperburuk kondisi janin. 3) Perkuatan sistem imun; Plasenta juga berguna sebagai suatu saluran perkuatan sistem imun janin terhadap kemungkinan serangan oleh bakteri, virus atau jamur yang dapat membahayakan kondisi janin.Sebagian besar sistem imun ini berasal dari ibu karena janin belum mampu mengembangkan sistem imun sendiri. 4) Distribusi oksigen; Karena fungsi utama plasenta pada janin yang terhubung langsung dengan sistem peredaran darah ibunya, maka plasenta juga berguna untuk pendistribusian oksigen ke janin. Oksigen diperlukan untuk berbagai macam proses metabolisme perkembangan janin yang berlangsung pada tiap sel atau jaringan. Kekurangan asupan oksigen pada janin berpotensi menyebabkan gangguan tumbuh kembang janin, baik secara fisik maupun mental. Pada keadaan normal, plasenta terletak di bagian atas rahim. Dengan kata lain, apa yang dialami Ibu Hanna di atas, merupakan keadaan tidak normal. Letak yang tak normal, kata Noroyono, mungkin saja terjadi tanpa diketahui penyababnya. Yang jelas, lanjutnya, kondisi yang 
tak normal itu memungkinkan ibu mengalami gangguan selama kehamilan. Misalnya pada kasus plasenta yang terletak di bawah, yaitu di bagian rahim (plasenta previa), membuat sebagian atau seluruh jalan lahir tertutup. 5) Penyebab khusus terjadinya plasenta previa tidak diketahui. Sebenarnya masalah plasenta previa tadi sudah ada di awal kehamilan namun sejalan dengan perkembangan kehamilan, ia bisa saja bergerak ke atas. "Itu bisa terjadi sampai kehamilan berusia 26 minggu. Lebih dari itu, letak plasenta akan tetap." Kasus seperti ini, kata Noroyono, cukup sering terjadi. Data menunjukkan, kasus ini dialami 1 dari 200 kehamilan. Umumnya dialami wanita pada kehamilan kedua dan seterusnya. lbu yang perokok atau pernah mengalami persalinan dengan bedah Caesar, juga berisiko memiliki plasenta previa antara 1,5 - 2 kali lipat. Kendati letaknya normal, plasenta mungkin saja terinfeksi. Baik itu infeksi yang berasal dari vagina atau penyebaran infeksi dari darah. Misalnya aliran darahnya terkena bakteri tifus. Jika bakteri itu menempel pada plasenta, maka akan terinfeksi dan mengakibatkan peradangan. Akibatnya bisa terjadi persalinan preterm (sebelum waktunya), jika infeksi tersebut terjadi sebelum kehamilan 37 minggu. "Paling sering terjadi infeksi pada plasenta akibat infeksi vagina. Orang awam mengenalnya dengan keputihan. Infeksi vagina itu bisa naik ke atas dan mengakibatkan infeksi plasenta atau selaput ketubannya," jelas Noroyono. Kasus lain dari keabnormalan plasenta adalah terlepasnya plasenta (solusio placente). Penyebabnya bisa karena hipertensi dan kekurangan asam folat. Bisa juga lantaran pendeknya tali pusat atau trauma karena kecelakaan. Pemisahan plasenta ini bisa terjadi sangat dini, pada kehamilan 20 minggu. Pada pemisahan plasenta, sel-sel darah pada dasar plasenta keluar secara spontan. Bisa kemungkinan terjadi pelepasan plasenta secara sebagian atau seluruhnya. Gejala awalnya, jika pemisahan plasentanya kecil, mungkin terjadi perdarahan ringan sampai sedang, ketidaknyamanan perut sebelah bawah, nyeri perut dan nyeri tekan pada rahim, dari ringan sampai berat. Mungkin juga terdapat kejang rahim (kram). Pada pemisahan yang besar terjadi perdarahan berat, warna darah merah hitam. Bunyi jantung bayi kurang terdengar, tidak teratur dan lambat sampai tidak terdengar. Perut terasa kencang dan nyeri bila ditekan, bisa parah dan mulai kontraksi kuat. Baik ibu dan janin akan banyak kehilangan darah. Komplikasi lain yang dapat terjadi seperti gagal ginjal. Ini dapat menyebabkan kematian ibu dan janin.

Dari penjelasan di atas sangat jelas bahwa plasenta berperan besar untuk kejadian BBLR pada janin. Tetapi pada penelitian yang telah dilakukan, disimpulkan bahwa plasenta tidak berhubungan secara signifikan terhadap kejadian BBLR ( $p$ value=1,00). Hal ini dimungkinkan karena dari keseluruhan responden yang diambil masalah plasenta sama-sama terjadi baik pada ibu yang melahirkan bayi BBLR maupun yang tidak BBLR, padahal secara substansi plasenta memiliki pengaruh yang besar terhadap kejadian BBLR pada janin (15).

\section{SIMPULAN DAN SARAN}

Berdasarkan hasil penelitian yang dilakukan didapatkan hasil tidak ada hubungan yang bermakna antara masalah plasenta dengan kejadian BBLR ( $p$ value $=0,587$ ) serta kehamilan multiple dengan kejadian BBLR ( $p$ value $=1,00)$. Tetapi walaupun demikian, perawat diwajibkan untuk lebih berperan aktif dalam memberikan pendidikan kesehatan bagi para wanita khususnya wanita usia subur untuk dapat lebih menjaga kehamilannya agar kejadian BBLR dapat dikurangi.

\section{UCAPAN TERIMA KASIH}

Terima kasih disampaikan kepada Direktur Poltekkes Kemenkes Tasikmalaya beserta jajaran pengelola di Unit Penelitian yang sudah memfasilitasi terselenggaranya penelitian ini, Direktur RSUD Dr. Soekardjo Tasikmalaya yang sudah memberikan izin kepada penulis untuk melakukan penelitian serta rekan-rekan perawat sebagai tim pengumpul data yang sudah bekerjasama selama tersenggaranya penelitian ini.

\section{REFERENS|}

1. MJ; HWD. Wong's essentials of pediatric nursing. (8th edition). 8th ed. St Louis: Elseiver; 2009.

2. Festi P. Analisis Faktor Kejadian BBLR di Kabupaten Sumenep [Internet]. 2013 [cited 2013 Sep 2]. Available from: https://id.scribd.com

3. Sulistyorini SS. Analisis faktor yang mempengaruhi kejadian BBLR di Puskesmas Perkotaan Kabupaten Banjarnegara [Internet]. 2015 [cited 2015 Sep 2]. Available from: 
https://id.scribd.com/doc/256540329/analisisbblr-1

4. Manuaba IB. IImu Kebidanan dan Penyakit Kandungan dan KB. Jakarta: EGC; 2008.

5. A DAJ. Birth weight effects on children's mental, motor, and physical development: Evidence from Twins Data. J Matern Child Heal. 2009;13:780-94.

6. Vohr, BR; Wright, LL; Dusic, A.M; Mele, R; Verter, J; Steichen, JJ; Simon, NP; Broyles, S; Wilson, DC; Bauer, CR; Delaney-Black, V; Yolton, KA; Fleiser B. Neurodevelopmental and functional outcomes of extremely low birth weight infants in the National Institute of Child Health and Human Development Neonatal Research Network, 1993-1994.

7. Hack M; Schlucter M; Cartar L; Rahman M; Cuttler L; Borawski E. Growth of very low weight infants to age 20 years. J Pediatr. 2013;112:30-8.

8. Resnick MB, Davis FE, Nelson RM, Eitzman DV BR. Developmental intervention for low birth weight infants: Improved early developmental outcome. Pediatr Off J Am Acad Pediatr. 1987;80:66-74.

9. Martika E. Hubungan BBLR dengan perkembangan motorik pada anak. [Internet]. UMY; $2012 . \quad$ Available from: thesis.umy.ac.id/t26273.pdf

10.Sastroasmoro; Ismael. Dasar-dasar metodologi penelitian klinis. Ketiga. Jakarta: CV Sagung Seto; 2010.

11.Luknis Sabri; Sutanto Priyo Hastono. Statistik Kesehatan. Revisi. Jakarta: Rajawali Pers; 2009.

12.Sutanto Priyo Hastono. Analisis Data Kesehatan. Jakarta: FKM UI; 2007.

13.I T. Faktor resiko kejadian berat badan lahir rendah di wilayah kerja Puskesmas Singkawang Timur dan Utara Kota Singkawang [Internet]. 2011 [cited 2015 Sep 2]. Available from: eprints.undip.ac.id/32555

14.Suradi \& Kristina (Ed). Manajemen Laktasi. Cetakan ke. Jakarta: Perkumpulan Perinatologi Indonesia; 2004.

15.Pantiawati I. Bayi dengan berat lahir rendah. Yogyakarta: Mulia Medika; 2010. 